\title{
(NÃO)TRABALHO E MASCULINIDADES PRODUZIDAS EM CONTEXTOS FAMILIARES DE CAMADAS MÉDIAS
}

\author{
(NO)WORK AND MASCULINITY PRODUCED \\ IN FAMILY CONTEXTS OF MIDDLE CLASS
}

\author{
Grazielle Tagliamento \\ Universidade de São Paulo, São Paulo, Brasil \\ Maria Juracy F. Toneli \\ Universidade Federal de Santa Catarina, Florianópolis, Brasil
}

\section{RESUMO}

Atualmente os sujeitos encontram-se diante de duas prerrogativas: a do tempo a serviço do trabalho e a do consumo como produtor de estilos de vida. Tais mandatos, aliados à escassez de empregos, fazem com que o indivíduo sem trabalho e sem emprego encontre-se em um terreno dramático permeado pelo agonismo. Ao se tomar esse contexto como pano de fundo, este texto irá apresentar as práticas cotidianas de duas famílias de camadas médias, nas quais o homem encontra-se sem trabalho remunerado, cabendo às mulheres realizarem tal atividade. A partir da análise dessas práticas, é possível verificar que ante as mesmas normas, num jogo de agonismo entre essas e as contingências impossibilitadoras de reiterá-las, múltiplas subjetividades e masculinidades afloram.

Palavras-chave: trabalho; masculinidades; famílias.

\begin{abstract}
Currently subjects are facing two prerogatives: working, as the main priority in life and consumption, as a producer of lifestyles. Such mandates, combined with the scarcity of jobs, put the individual without work and without employment is in a dramatic field which is permeated by agonism. When you take this context as background, this text will present the daily practices of two families of middle class, in which the man is unemployed, and the woman has to take the responsibility of having a job. From the analysis of such practices, it can be attested under the same norms, in a game of agonism between these and the contingencies that preclude the reiteration of them, multiple subjectivities and masculinities emerged.
\end{abstract}

Keywords: work; masculinities; families.

Nas sociedades contemporâneas, os sujeitos vivem sob a égide de dois sistemas de tecnologias de poder: o disciplinar e o regulador (Foucault, 2005). O primeiro teve seu início por volta dos séculos XVII e XVIII, caracterizando-se por técnicas disciplinares sobre os corpos, que objetivavam seu adestramento para que os indivíduos pudessem ser manipulados como corpos dóceis e úteis.

A partir da metade do século XVIII, outras tecnologias de poder são somadas às anteriores. São somadas na medida em que não há a exclusão das disciplinares, e sim a existência das duas formas de poder concomitantemente, a disciplinar e a reguladora, que emerge nesse momento. Há agora um deslocamento do foco do poder, que antes era dirigido aos corpos, um "anátomo- poder", que passa a ser orientado à vida dos sujeitos, um "biopoder" (Foucault, 1999b).

Essa nova técnica do poder não se dirige mais a indivíduos isolados, e sim à população. $\mathrm{O}$ biopoder consiste no controle da população global, por meio da regulação das taxas de natalidade, longevidade, mortalidade, enfim, dos estados de vida da população. Busca-se com esse tipo de poder otimizar a vida, e não mais uma maximização da força (Foucault, 2005). Decorre dessa alteração do campo de efetivação do poder, a regulação de todo o campo social, não se restringindo ao interior das instituições. O que se vê é justamente uma quebra de fronteiras, de delimitações de ações do poder, uma vez que esse se encontra intrínseco a todas as relações, fazendo com que o campo de sujeição também seja 
dilatado e completo. Tal regulação proporciona que as vidas sejam empregadas ao capital, independentemente se são vidas assalariadas ou desempregadas, jovens, crianças, enfim, todas as vidas. A existência mútua dessas duas formas de poder, a disciplinar e o biopoder, tem em comum a norma, que permite a manutenção do equilíbrio entre a disciplina do corpo e a ordem aleatória da população. Com isso, a norma pode ser aplicada tanto a um corpo que se deseje disciplinar quanto à regulação de uma população (Foucault, 1999b). Esse elemento, em comum, propicia a edificação de uma "sociedade de normalização", na qual coexistem o corpo e a vida, a individualização e a massificação, a disciplina e a regulamentação.

Nessa nova conjuntura, não é possível realizar a ligação estreita entre trabalho e a disciplina da fábrica, devido à emergência do trabalho imaterial. Essa forma de trabalho produz, entre outras coisas, serviços. Isto é, "como a produção de serviços não resulta em bem material e durável, definimos o trabalho envolvido nessa produção como trabalho imaterial - ou seja, trabalho que produz um bem imaterial, como serviço, produto cultural, conhecimento ou comunicação" (Hardt \& Negri, 2001, p. 311).

Ao colocar a vida como ferramenta de produção, adentra-se no espectro de comunicação da vida, sendo que essa produção somente é possível quando em relação com outras ferramentas, com outras vidas. Em outras palavras, "a produtividade, a riqueza e a criação de superávits sociais hoje em dia tomam a forma de interatividade cooperativa mediante redes lingüísticas, de comunicação e afetivas" (Hardt \& Negri, 2001, p. 315).

Dessa forma, o trabalhador exerce suas atividades profissionais em todos os momentos de sua vida, não se restringindo a uma empresa. Ele é ao mesmo tempo objeto e sujeito do trabalho, na medida em que é uma ferramenta de produção (objetivação) e se sujeita às normas engendradas nesse processo de produção (subjetivação).

O capitalismo, ao utilizar o biopoder como ferramenta de seu exercício e expansão, conseguiu atingir o centro de produção de subjetividades, uma vez que a produtividade de materiais não se encontra mais, na contemporaneidade, restrita à relação entre indivíduo e natureza, e sim nos processos sígnicos, cognitivos e comunicativos engendrados nas relações de produção. Nota-se, então, que anteriormente o capitalismo agia sobre o processo de produção de subjetividades, sobre a relação do indivíduo com as coisas, e hoje age sobre a própria subjetividade, já que seu domínio encontra-se exatamente no modo de agir do sujeito, na sua vida.

Nessa nova configuração diminui cada vez mais a existência de empregos fixos, aumentam os trabalhos informais. Essa alternativa ao emprego coloca o indivíduo frente à instabilidade do mercado ao mesmo tempo em que lhe proporciona certa liberdade, uma vez que ele não se encontra vinculado diretamente aos mecanismos de controle das empresas. No entanto, mesmo desempregado, a sua existência permanece regulada por normas que estabelecem a necessidade do trabalho, haja vista a inevitabilidade do uso do tempo para o trabalho, e do consumo. Esta última encontra-se intimamente relacionada à sociedade de consumo contemporânea, na qual o setor de Marketing das empresas ocupa lugares de destaque nos modos de produção, o que torna a propaganda um eficaz meio de controle da sociedade.

Diante destas prerrogativas, a do tempo a serviço do trabalho e a do consumo como produtor de estilos de vida, aliadas à escassez de empregos, o indivíduo sem trabalho e sem emprego encontra-se em um terreno dramático permeado pelo agonismo ${ }^{1}$. De um lado, têm-se as normas e, de outro, se encontram os sujeitos buscando sua autorregulação para agirem de acordo com tais normas, numa tentativa de se enquadrarem a essas. O que torna a situação de desemprego e a própria procura por trabalho modos de subjetivação, pois produzem modos de vida, e modos de objetivação, já que a partir dessas circunstâncias o indivíduo é o seu próprio objeto a ser trabalhado. Vislumbram-se, assim, dois elementos que regem a produção de subjetividades dos indivíduos contemporaneamente, a ética e a norma. Os indivíduos possuem um conjunto de normas e valores preconizados pelo capital e por seus dispositivos de poder, os quais os impelem a ter um cuidado constante consigo, para assim se adequarem a tais normas.

Ao se tomar esse contexto como pano de fundo, este texto irá apresentar as práticas cotidianas de duas famílias de camadas médias, nas quais o homem encontra-se sem trabalho remunerado, cabendo às mulheres realizarem tal atividade. As histórias dessas famílias foram construídas a partir de falas obtidas por meio de entrevistas realizadas com três membros de cada uma (pai, mãe e filha), que foram os que se disponibilizaram a concedê-las. Para a coleta dos comentários desses sujeitos, lançou-se mão de entrevistas semiabertas, compostas por um roteiro com perguntas geradoras. Todas as entrevistas foram áudio-gravadas em fitas K7, com permissão prévia dos/as entrevistados/as por meio da assinatura do Termo de Consentimento Livre Esclarecido, e, posteriormente, foram transcritas na íntegra para fins de análise.

O material obtido por meio das entrevistas foi transformado em um discurso das famílias sobre suas práticas diante da situação de não provimento financeiro do homem/pai. Para a análise desses discursos, realizouse primeiramente uma descrição, mas já efetuando alguns diálogos com a literatura especializada, das 
práticas cotidianas de cada família, separadamente. A partir da descrição das práticas cotidianas foi possível verificar e analisar as normas que as engendram e as produzem, bem como os processos de subjetivação dos sujeitos, suas resistências e as subjetividades que ali emergiram.

\section{As práticas cotidianas}

\section{Família Santos $^{2}$}

Marcos e Aline conheceram-se e casaram-se quando ministravam aulas para os ensinos Fundamental e Médio da rede pública, ambos eram professores. Recém-casado, Marcos entendia que deveria galgar um emprego que lhe propiciasse um maior rendimento. Com esse intuito, fez um concurso e passou a exercer sua atividade profissional em um banco. Nessa época, a família Santos possuía uma vida muito confortável, pois Marcos ganhava o suficiente para proporcionar uma ótima qualidade de vida a sua família, enquanto Aline continuava desenvolvendo o seu trabalho "por prazer"3, sendo sua renda destinada as suas despesas pessoais, complementando a renda de Marcos.

O Marcos ganhou bem mesmo, ganhou dinheiro, ganhava muito mais que eu. ... a minha grana era mais para as minhas coisas, para as crianças, e para as minhas coisas mais pessoais assim, era um complemento, mas a dele era a base de tudo, e a gente vivia bem... (Aline).

Marcos não estava muito satisfeito com seu emprego no banco, e com o estabelecimento do Plano Cruzado ou Inflação Zero, o setor bancário sofreu uma forte crise. Mediante esses fatos, resolveu montar uma empresa juntamente com alguns colegas. Porém, essa empresa não conseguiu se consolidar no mercado, tendo que encerrar as suas atividades. Marcos trabalhou posteriormente em diversas empresas, nas quais possuía o cargo de gerente. Com isso, os seus rendimentos passaram a oscilar, ora ele estava empregado, recebendo um salário, ora não, até o momento em que resolveu se lançar novamente como empresário. Com essas oscilações o rendimento fixo da família passou a ser o de sua companheira, sendo que nos dois últimos anos, após o fechamento de sua última empresa, passou a ser o único.

Essa inversão no sustento financeiro familiar é entendida e vivenciada de maneira incômoda pela família, e como motivos para tal aborrecimento são apontados: o fato de o rendimento de Aline não ser o suficiente para que Marcos pudesse desenvolver seus empreendimentos, como a sua invenção de uma ferramenta; de Aline trabalhar muito; e a não realização profissional e pessoal de Marcos, que é visto como frustrado profis- sionalmente por não ter conseguido encontrar algo que o satisfizesse e que tivesse dado certo.

No entanto, essa mudança não propiciou grandes alterações nas posições atribuídas aos seus membros, constituindo-se a maior queixa. Essa reclamação é decorrente da expectativa que a família possuía de que, por estar sem trabalho e Aline trabalhando muito, Marcos pudesse auxiliar nas atividades domésticas, o que não ocorreu. As justificativas trazidas para essa não alteração é a de que a mulher não é vista nessa família como provedora e a de que Marcos sempre procurou demonstrar que estava trabalhando. Outro aspecto apontado é o de que ele não foi "preparado" para assumir as atividades domésticas, que socialmente eram, e frequentemente ainda são, atribuídas às mulheres. Nas palavras de Marcos: "eu não tive o preparo [risos] operacional, psicológico, enfim. Jamais eu me via na situação de dono de casa, tendo de fazer as coisas que geralmente as mulheres fazem e colocando ela na situação de provedora".

Há uma lógica operando aqui que liga sexo diretamente a gênero ${ }^{4}$ e seus atributos, e vice-versa, que consiste em uma atribuição à mulher dos espaços domésticos. Essa visão é vivida e transmitida por gerações, o que acaba por naturalizar a casa como um espaço feminino ou, ainda, feminilizante, fazendo com que o homem se afaste desse lócus para não colocar em "risco" a sua masculinidade. Este processo de transmissão geracional e cultural faz com que Marcos aja performaticamente reiterando tal proposição, enquanto a família evidencia uma resistência a essa norma, ao desejar e não ver problemas que Marcos ocupe tal espaço.

Marcos está sempre se empenhando para realizar algum tipo de trabalho, fato que tem a ver com a procura em não recair no ócio, como se a todo o momento o seu tempo devesse estar ocupado. Pois, há a dificuldade em lidar com a falta de emprego ou de perspectivas e projetos se encaminhando. Ou seja, "a dificuldade é você cair naqueles vazios, das armadilhas que a vida apresenta. E que você nem sempre está preparado" (Marcos).

Em uma sociedade regulamentada pela regra do trabalho, os indivíduos não são "preparados" para exercer o ócio - que é uma das expressões de autonomia do indivíduo -, já que esse não pode ser regulado e disciplinarizado totalmente pelo modo capitalista de produção. Dessa maneira, o ócio é entendido como uma transgressão, como uma linha de fuga à norma, ao trabalho. Resumindo, "na nossa sociedade onde o trabalho é a regra, o ócio torna-se uma espécie de desvio" (Foucault, 1999a, p. 346).

A busca de Marcos em não ocupar o espaço da casa, aliada ao fato de ter de sempre estar mostrando a sua não acomodação, de estar trabalhando, fez com que 
não tivesse uma aproximação com os filhos. Como se o relacionar-se com eles e o dialogar o aproximassem do espaço doméstico, além de possivelmente ter de demonstrar os seus sentimentos e suas fraquezas, principalmente aquelas relacionadas ao seu lado profissional. No entanto, os filhos percebiam a situação delineada, principalmente Marta, que era muito ligada à mãe e sua confidente. Ela se incomodava ao ver sua mãe trabalhando muito e seu pai não, chegando a chamá-lo de "preguiçoso".

Se nos últimos dois anos Marcos vem trabalhando no desenvolvimento de uma nova ferramenta, por que ainda afirmar que ele não trabalha e é um preguiçoso? Para responder a essa pergunta, é necessário analisar três aspectos, que são interligados e justapostos:

(a) Por ser um trabalho que demanda estudos e pesquisas, um trabalho intelectual, antes de se objetivar na ferramenta em si, o processo de invenção torna-se um trabalho imaterial e não palpável, e, consequentemente, menos valorizado. Esse tipo de trabalho não fica circunscrito tão somente ao dispêndio físico, expandese às aptidões cognitivas, possuindo como meta final a acumulação de informações, para consequentemente materializar-se em uma tecnologia que servirá para um trabalho material. Nesse processo há, portanto, a agregação de um valor adicional ao produto do trabalho, a criatividade intelectual (Vercellone, 2003).

A materialidade desse tipo de trabalho, o imaterial, requer a comunicação entre os indivíduos, por se tratar de um trabalho de natureza cognitiva e por sua valorização afetiva. Então, Marcos, ao não manter uma relação dialógica com seus filhos, não tem a possibilidade de compartilhar com esses o seu trabalho. Como eles poderão, portanto, inferir que o pai trabalha?

(b) Remete à necessidade de possuir rendimentos, já que nessa empreitada passa-se por um longo período somente investindo para depois ter um retorno financeiro. Com isso há um elo entre trabalho e rendimento, ou seja, se não há rendimento, consequentemente não há trabalho, e o pai é "preguiçoso". Esse raciocínio é decorrente da noção de que o trabalho deve ser comprado por alguém, mesmo que seja na forma de seu produto final, fazendo com que o valor do trabalho esteja intimamente interligado ao valor do produto final ou do esforço e tempo que são despendidos para alcançá-lo (Foucault, 1999a).

Então, ao se considerar que o pai não trabalha, como ele poderá sustentar a família financeiramente? Ao partir do pressuposto de que o prover e o trabalho são considerados como deveres legados aos homens, Marcos não cumpre com seus deveres, e o que lhe resta é ser denominado de "preguiçoso".

(c) Refere-se à ideia de uma ligação estreita entre trabalho e emprego. Uma vez que se encontra desempregado, não vinculado a uma instituição, Marcos trabalha nos espaços que desejar e nos horários que forem mais oportunos a ele. É possível notar resquícios de uma lógica capitalística nessa relação estabelecida entre trabalho e emprego, na qual é necessária a ligação do indivíduo ao aparelho de produção para o qual trabalha. Ou seja, o indivíduo deve estar concretamente ligado aos meios de controle do capitalismo, sejam eles disciplinares e/ou reguladores. "É preciso a operação ou síntese operada por um poder político para que a essência do homem possa aparecer como sendo a do trabalho" (Foucault, 1999a, p.357).

Ao exercer a sua existência de maneira criativa e autônoma e, ainda, não ser assalariado, Marcos encontra uma fissura no modo de produção e também no âmbito da produção de masculinidades, desestabilizando-os. Mas essa regra ainda vale para a família e a todo o momento ela é requerida, o que faz com que o grupo familiar entre num jogo permeado pelo agonismo entre a regra e a sua resistência.

Essa ótica orientada para a busca de emprego, a concepção de que o homem deve sustentar financeiramente a família e, de certa maneira, pela pressão dessa e de sua família de origem, fez com que Marcos buscasse se inserir no mercado de trabalho por diversas vezes. Mas, como já havia ocupado cargos elevados em suas atividades profissionais, não se sujeitava a aceitar qualquer proposta de emprego. A partir dessas circunstâncias, ele foi se retraindo e desacreditando no seu potencial, o que deixou e deixa Marcos infeliz, conforme afirma sua companheira: "eu acho que ele não foi feliz nesse período, não está feliz" (Aline).

É possível perceber uma relação entre autoridade e trabalho que pode ser visualizada na relação estabelecida entre Marcos e os filhos, na qual ele mantém-se "autoritário" e por vezes "arrogante" com esses, como em uma tentativa de afirmar que está realmente trabalhando e de não perder a posição de autoridade e o respeito dos filhos. Com isso, ele pode manter sua posição de homem, pai, trabalhador e provedor. Nessa busca pela manutenção dessa posição, por meio do " $a u$ toritarismo", Marcos acabava se desentendendo com Aline exatamente quando ela era "autoritária", como se essa situação abalasse a sua masculinidade.

Nesse contexto familiar, pode-se, então, apreender que por mais que a mulher exerça uma atividade profissional, é ela ainda quem deve também exercer as atividades domésticas, cabendo ao homem somente a atividade profissional. A partir dessa prerrogativa, é possível ver a mulher ocupando várias posições sociais e atributos - profissional, dona de casa, provedora, sentimental, "autoritária", mãe -, enquanto o homem ainda só pode desempenhar as de trabalhador e de " $a u$ toritário", podendo demonstrar carinho e afeto somente para com sua companheira. 


\section{Família Rodrigues ${ }^{6}$}

Quando Gabriel e Margarete casaram-se, ela cursava a graduação de Letras e ministrava aulas particulares, enquanto que ele era funcionário de uma empresa, na qual trabalhou durante um ano. Após trabalhar nessa empresa, lançou-se como engenheiro civil autônomo, vindo a abrir sua própria construtora. Margarete, ao concluir seus estudos, abriu uma escola de educação infantil, onde trabalhou durante cinco anos. Posteriormente, passou em um concurso para ministrar aulas na rede estadual de ensino e para diretora de escola da rede municipal, sendo que paralelamente ministrava aulas para a rede privada.

A construtora de Gabriel teve uma ótima aceitação no mercado, o que lhe possibilitava obter elevados rendimentos. Assim, Margarete desfrutava da possibilidade de trabalhar sem se preocupar em lograr bons salários e fazia apenas o que lhe proporcionava satisfação pessoal. Seu trabalho era considerado pelo companheiro e seus amigos como não necessário, já que ele teve uma forte ascensão profissional e propiciava uma ótima qualidade de vida à família, além de afastá-la das atividades domésticas. Gabriel entendia que Margarete deveria ficar em casa e cuidar das crianças e do lar. No entanto, ela pontuava a todo o momento que não era dona de casa e manteve sua carreira profissional, pois essa era fonte de muita gratificação pessoal. Como exemplo dessas situações, têm-se as falas de Margarete e Roberta: “ $A s$ pessoas me criticavam muito por trabalhar" (Margarete). "Ele falava: porque essa casa não tem dona de casa, porque não tem nada, você não olha isso. Ai minha mãe falava: mas eu não sou dona de casa, eu trabalho fora e tal" (Roberta).

Nota-se que Margarete resistia à norma estabelecida pela sociedade em que vivia, a qual pregava que a mulher, para exercer bem a sua posição social de mãe, deveria ocupar-se do lócus familiar, a casa. Ainda que pudesse trabalhar fora, a sua prioridade deveria ser a casa, os filhos e o marido, fato que leva muitas mulheres, que optam ou necessitam exercer atividades profissionais, a exercerem uma dupla jornada de trabalho. A resistência de Margarete ocorre justamente na fissura dessa própria norma, ou seja, ao repetir o padrão inteligível, trabalhando fora e cuidando dos filhos (sua relação com os filhos era de forte proximidade), ela consegue agregar um padrão ininteligível: o de se eximir do cuidado da casa, uma vez que Gabriel e a sociedade entendiam que era de sua responsabilidade e seu dever se ocupar dessas atividades. Importante salientar que o cuidado da casa não é entendido, aqui, como realizar os afazeres domésticos, uma vez que essa mulher não os precisava efetivar por ter uma empregada. O que a norma estabelece para ela, então, é gerenciar o lar, assim como a funcionária que exerce tais serviços domésticos, posição da qual Margarete exime-se por não se nomear como dona de casa.

Nesse período, a família vivia muito bem financeiramente, mas as relações íntimas familiares eram embramadas. Essa situação decorria do fato de Gabriel trabalhar exaustivamente, sendo essa a sua prioridade, $o$ que não lhe permitia desfrutar de relações mais intensas com seus filhos e sua companheira. Quando havia a possibilidade de aproximação, essa ocorria mais com Margarete do que com os filhos. Com isso, não havia muito tempo para ficar com a família, e o pouco tempo que possuía não era aproveitado, por estar estressado com suas atividades profissionais, gerando embates em suas relações. Assim, ao invés dessas serem permeadas pelo diálogo, havia a imposição de suas ideias, fato que era visível até mesmo por seu alto tom de voz. Essa imposição pode estar relacionada com a circunstância de ele prover o sustento financeiro, como se, por ganhar muito dinheiro e proporcionar uma vida confortável para a família, fosse detentor de certa autoridade sobre os demais.

Em 1999, porém, Gabriel teve de solicitar a falência de sua construtora, época em que a família passou por dificuldades, tanto de ordem financeira quanto afetiva. As de ordem financeira relacionavam-se com a impossibilidade de Gabriel continuar provendo o sustento financeiro e com o fato de Margarete não obter rendimentos suficientes para a manutenção do padrão de vida que possuíam. Tiveram, então, que reduzir os gastos familiares, como não ter mais carro, não ter mais empregada doméstica, diminuir as despesas alimentares e, por vezes, aceitar pequenos auxílios financeiros das mães do casal, como, por exemplo, para pagar taxas de inscrições dos vestibulares da filha. Nas palavras de Gabriel: "foi uma fase que às vezes não tinha dinheiro nem para comprar alimentação, não tinha mais carro".

A possibilidade de Margarete trabalhar teve influências da sua família de origem, na qual sua mãe sempre exerceu uma profissão, ocupando até mesmo cargos políticos. Essa postura da mãe de Margarete era, segundo a família, rara, uma vez que moravam em uma cidade constituída por pessoas conservadoras, as quais entendiam que as mulheres deveriam se ocupar das atividades domésticas, e viviam em uma época em que poucas mulheres trabalhavam fora de casa no município em que residiam.

A falência da empresa de Gabriel deixou-o muito frustrado, pois seus planos profissionais não haviam dado certo, e ele não poderia mais prover financeiramente sua família, além do fato de ter que pedir dinheiro para a sua companheira. Essa situação fez com ele ficasse doente e deprimido, não tendo mais forças para sair de casa ou até mesmo para deixar a cama. No início, por diversas vezes levantava cedo como se fosse trabalhar e se dava conta de que não poderia 
mais o fazer. Algumas vezes conseguia visualizar uma perspectiva e tentava procurar um novo emprego, mas não era bem-sucedido.

Concomitantemente a isso, a família era excluída pela sociedade, já que as pessoas o viam como fracassado, como incapaz de prover a família, chegando a não dirigirem a palavra a ele. Gabriel era marginalizado por não ter emprego e por não ter crédito para poder comprar e, consequentemente, pagar as contas da família. "Porque em qualquer lugar que você vai você não pode pagar com cheque, não pode ter cartão de crédito. É complicado" (Gabriel).

A marginalização social sofrida por Gabriel pode ser decorrente das normas regulatórias de gênero e das do mercado capitalista voltado ao consumo. A primeira estabelece que, por ser homem, deva trabalhar e prover o sustento financeiro da família. No entanto, Gabriel não se encontra atuando segundo essa norma; ainda que tente segui-la não obtém sucesso, o que o deixa fora da zona de inteligibilidade social, como se fosse invisível aos olhos da sociedade. Essa invisibilidade não se dá como uma metáfora, e sim na concretude das relações, como, por exemplo, o fato das pessoas cumprimentarem a sua companheira e não o cumprimentarem. "As pessoas deixam claro, ele fica sempre o último da fila..." (Margarete). Assim, as posições sociais, como a de homem provedor, são "princípios organizadores embutidos de práticas materiais e arranjos institucionais, que são as matrizes de poder e discurso que me produzem como um ‘sujeito' viável” (Butler, 1998, p. 24).

A segunda norma está intimamente ligada à sociedade de consumo moderna, a qual é fruto do capitalismo. Essa estabelece que é necessário consumir para poder possuir um status social. Ao consumir, o sujeito denota que trabalha e possui rendimentos, alimentando o modo de produção capitalista que sobrevive por meio do lucro. Gabriel, ao não consumir e não trabalhar, não é considerado como útil e produtivo para a sociedade, e sim um incômodo por não reiterar a norma, por se encontrar justamente à margem desse sistema.

Margarete também se sentia mal com essa situação, por diversos fatores: ter de trabalhar muito, ver Gabriel nessa condição e por ter de pagar as dívidas oriundas da falência empresarial. Essa situação gerava grande desconforto e, às vezes, ela agia de maneira "autoritária", como se, por estar pagando as contas, o companheiro devesse obedecê-la. Logo, ocorriam muitas brigas entre o casal, e chegaram até mesmo a cogitar a hipótese de separação conjugal. Entretanto, o casal optou, segundo a família, por se despojar das posições sociais que eram impostas historicamente a cada um, visando uma maior flexibilidade de exercício de suas atribuições, isto é, ao descolarem as posições que eram coladas aos seus corpos, conseguiram transitar entre elas.
Nesse período, a configuração das posições exercidas pelos membros da família foi alterada, na medida em que Gabriel deixou o seu lugar de pai provedor ausente, por vezes, e passou a ocupar o de filho. Assim, a família passou a ser constituída pela mãe juntamente com seus três filhos. Tal (re)configuração se constituiu à medida que Margarete passou a sustentar e a cuidar do marido, a incentivá-lo a não desistir de sua vida. $\mathrm{Ou}$ seja, "nós somos os três filhos dela. Até brinco quando ela faz alguma coisa, cuidado porque você tem os seus três filhos para cuidar" (Gabriel).

Nesse cenário, os filhos viam-se perdidos, pois de um lado havia a mãe, que ora compreendia a situação do pai, ora não, e de outro se encontrava o pai, sentindo-se constrangido e sofrendo pelo que acontecia. Localizavam-se assim entre o "fogo cruzado" (Roberta). Sentiam-se também aflitos, porque haviam perdido a referência que possuíam até então do pai, uma vez que esse era aquele que dava a palavra final em casa e passou a se eximir dessa posição, delegando-a à mãe. O que é compreensível, já que ele também ocupava o lugar de filho na família, tendo que se dirigir a Margarete para pedir dinheiro e, com isso, realizar os seus desejos, suas vontades. Portanto, Gabriel não se sentia habilitado para falar de sua posição de pai, de autoridade, já que a fala depende de quem é o sujeito que a profere e da posição ocupada por esse, por meio de um direito que é reconhecido institucionalmente (Foucault, 2004).

Diante de todas essas circunstâncias que causavam aflições, Gabriel, segundo os membros do grupo familiar, tinha algumas opções, como embriagar-se, continuar deprimido, fazer terapia ou voltar a estudar. Como a família não tinha condições de pagar por uma terapia e como Margarete trabalhava em uma faculdade e havia a possibilidade de conseguir uma bolsa de estudos para Gabriel, esse decidiu voltar a estudar e fazer o curso de Direito. Essa escolha é decorrente do apoio e incentivo que teve da família, suporte que é considerado como fundamental para que ele não se tornasse "alcoólatra, porque tem hora que o sufoco é tão grande que você [emocionado] sente a necessidade [pausa] de beber, de fugir do mundo. Se não tiver [choro] um apoio da família não vence. Então, é um baque muito forte" (Gabriel).

A nova formação de Gabriel abriu o seu leque de possibilidades de atuação profissional, pois poderia desenvolver atividades como engenheiro e advogado. Assim, passou a efetivar pequenos trabalhos nessas áreas, bem como a realizar os serviços domésticos, tornando-se um "dono de casa", e os serviços de escritório para a companheira, como ir ao banco. Nessas circunstâncias, quando ele se encontra trabalhando fora de casa, por mais que não tenha grande remuneração, sente-se bem por estar fazendo algo: "Pelo menos distrai" (Gabriel). 
Assumir as atividades domésticas foi consequência do aumento da carga horária de trabalho de sua companheira e de não poderem pagar uma empregada para cuidar da casa. No início, essa nova posição foi vivenciada de maneira intranquila por ele, uma vez que se sentia incomodado em ter de, por exemplo, ir ao supermercado, sendo que não trabalhava. Isto é, não se sentia bem em fazer compras por não trabalhar e ter de encontrar com moradores da cidade que por vezes o marginalizavam, e, ainda, por comprar com o dinheiro originado do trabalho de Margarete. No entanto, com o passar do tempo, Gabriel foi se acostumando, e hoje gosta e não vê problemas em cozinhar, limpar, enfim, em realizar os afazeres domésticos. O fato da família não ver distinção entre trabalho destinado ao homem e trabalho destinado à mulher, numa perspectiva mais igualitária, proporcionou que ele realizasse tais atividades e que sua companheira trabalhasse fora de casa.

Percebe-se, portanto, que a maior dificuldade não reside na mulher ter uma carreira profissional, e sim no não trabalho do homem e na sua não contribuição financeira. Hipótese que pode ser mais bem contemplada nas práticas dessa família, nas quais Gabriel sente-se frustrado por não prover a família e principalmente por não trabalhar, e Margarete, mesmo compreendendo que ela é quem tem de sustentar no momento a família, incomoda-se ao vê-lo impossibilitado de ajudá-la. Nos dizeres de Margarete: "Eu falo: olha, nós estamos juntos há 31 anos, você me sustentou 27, eu to só com 5, calma, quando você chegar no 31 eu te sustentando, você vai ganhar um cartão vermelho".

Essas circunstâncias serviram como pano de fundo e molas propulsoras de grandes mudanças nas relações familiares. Gabriel já não era mais "autoritário" e arrogante. Passou a ter uma postura mais igualitária e humilde com a família, além de possuir mais tempo para ficar em casa e, consequentemente, se relacionar intensamente com os seus. O vínculo passou a ser permeado pelo compartilhar, por diálogos. Os sujeitos, conforme o grupo familiar, despiram-se do "egoísmo" e uniram-se justamente a partir do sofrimento, frustrações e alegrias que sentiam, decorrentes das alterações ocorridas em suas práticas cotidianas. Nessa perspectiva, Margarete afirma: "É isso que eu acredito que um dia... as pessoas ao se despirem do egoísmo exacerbado da sociedade, elas vão chegar a isso... e é a isso que eu tô chegando no meu casamento, eu tô muito feliz...".

O diálogo na família propicia que compartilhem uns com os outros as suas incomodações. Situação que ocorre, por exemplo, quando Gabriel realiza um trabalho e chega um pouco mais exaltado em casa; nesses momentos, é solicitado que abaixe o tom de voz, que não se estresse com o trabalho, e ele escuta e pede desculpas por sua atitude, o que não ocorria anteriormente.
Mesmo permanecendo em Gabriel uma "ferida aberta" por ter "fracassado" em sua atuação enquanto profissional e provedor, e Margarete conservando sentimentos contraditórios em relação ao companheiro, com "vontade de bater a manhã inteira e abraçar à tarde" (Margarete) por ter de pagar as suas dívidas, após o turbilhão inicial a família vê que esse acabou por varrer as distâncias que existiam entre seus componentes, fazendo com que se (re)conhecessem e se "enamorassem".

No momento, Gabriel encontra-se com um escritório montado em sua cidade, trabalhando em uma construção e obtendo pequeno retorno financeiro. A família sente muita satisfação em vê-lo trabalhando e não mais adoentado, e infere que suas doenças eram decorrentes da falta de trabalho. Em outras palavras: "a tua depressão tem nome, é falta de trabalho. Que ele fica sem trabalho, a pressão começa a subir, ele começa a ter problema de artrose, ai ele fica de cama, ai ele fica mal" (Roberta).

Delineiam-se, assim, três momentos na história de vida dessa família: (a) durante o qual o pai provê o sustento e é distante da família, além de ser extremamente "autoritário", enquanto a mãe trabalha, é próxima dos filhos, sensível e emotiva; (b) o da crise, quando o pai deixa de prover e se vê impelido a ficar em casa, não tendo mais em quem mandar, destituindo-se, em parte, da característica de "autoritário". Afinal, "chegou uma época que ele só tinha um cachorro para mandar e foi triste porque o cachorro também não escuta" (Margarete). Gabriel passa a se demonstrar frágil e emotivo. A mãe tem, então, de assumir o sustento financeiro, o que a leva a se portar de maneira mais competitiva, porém sem perder a docilidade. Em outras palavras: "eu virei um homem, eu sou um homem, eu só não tenho pinto, mas eu virei um homem, porque eu pago conta, eu tenho que brigar, eu estou com características competitivas no mercado" (Margarete); e (c) o momento em que a mãe sustenta a família e o pai contribui quando tem algum retorno financeiro de seus trabalhos e exerce as atividades domésticas, aliado à maior proximidade desse com a família e vice-versa. Nessa fase, tanto Margarete quanto Gabriel são emotivos, sensíveis; e ela continua sendo competitiva, "guerreira", enquanto Gabriel, quando trabalha e tem um retorno financeiro, assume novamente uma postura mais "autoritária".

As características que emergem nessa última fase já existiam anteriormente à crise. No entanto, no contexto em que viviam, algumas se sobressaíam mais do que outras. Como se, por terem posições bem definidas - Gabriel trabalha e sustenta financeiramente a família e possui atitudes "autoritárias", e Margarete trabalha, mas é coadjuvante nas despesas da casa, além de cuidar dos filhos e ser sensível -, possuíssem características 
que condiziam com suas posições, ocupadas na família e socialmente. Havia uma ligação entre sexo e gênero, isto é, a mulher tinha atributos femininos, e o homem os masculinos. Mas, no momento da falência da empresa de Gabriel, houve uma crise nesse sistema, e a mulher passou então a atuar performaticamente mais no gênero masculino e o homem no feminino, o que fez com que questionassem até mesmo seu sexo, por não haver mais uma ligação direta entre sexo e gênero. Como se voltassem a si e questionassem: será que estou de acordo com a norma? Será que sou mulher ainda? Será que sou homem ainda? Afinal, essa norma reitera que o masculino corresponde ao homem e o feminino à mulher. Hoje, possuem uma relação que permite que deslizem nas várias posições de gênero e, por conseguinte, demonstrem atributos tanto masculinos quanto femininos.

\section{A norma do trabalho e a produção de masculinidades}

Há todo um conjunto de técnicas que visam a regular e disciplinarizar os indivíduos para que esses reiterem as normas e morais de gênero, e assim possam ser reconhecidos como sujeitos. Essa regulação fez com que os sujeitos travassem lutas cotidianas entre o que é esperado socialmente e a impossibilidade de exercerem tais mandatos em suas vidas, sendo que, por meio desse jogo agonístico, emergiram resistências e modos de vida e masculinidades diversas.

A produção de masculinidades é orquestrada por mecanismos e procedimentos, estratégias e táticas de poder que atuam na criação de práticas qualificadas como verdadeiras e na desqualificação de outras, tidas como falsas. A eficácia desse processo de normalização se dá pela atuação da família como instituição reguladora. $\mathrm{O}$ controle perpassa pelo social e penetra na intimidade dos vínculos familiares, a fim de propiciar a reiteração das normas. A família age como uma espécie de panopticon ${ }^{7}$, levando seus membros a se autogovernarem e a realizarem um contínuo cuidado sobre si, para que possam ser reconhecidos pelos outros. Tal processo é viabilizado pela própria regulação pormenorizada do contrato de casamento e dos seus efeitos, há prescrições legais, políticas e sociais sobre as formas de relacionamento e as posições que cada indivíduo deve exercer.

A existência de tais prescrições está condicionada a sua contínua repetição e reiteração, os sujeitos são impelidos paulatinamente a exercerem condutas condizentes com essas prescrições, como, por exemplo, os homens terem de constantemente se dedicarem ao trabalho para que, assim, possam ser considerados e percebidos na posição de "homens". É importante salientar que esse processo de repetição acaba por naturalizar as normas regulatórias de gênero, como se essas fizessem parte da "essência" dos sujeitos. Perspectiva que vai ao encontro do que Butler (2003) apregoa acerca do gênero, ao afirmar que esse "é a estilização repetida do corpo, um conjunto de atos repetidos no interior de uma estrutura regulatória altamente rígida, a qual se cristaliza no tempo para produzir a aparência de uma substância, de uma classe natural de ser" (p. 59).

Desse modo, os homens e as mulheres se veem constantemente atuando performaticamente segundo essas normas, repetindo-as e transmitindo-as de geração em geração. São impostos determinados atributos e posições para que os sujeitos sejam considerados homens ou mulheres. Esses mandatos prescrevem que para ser homem é necessário trabalhar, prover a família e possuir uma posição de autoridade, e para ser mulher é preciso ser sensível, dona de casa e cuidadora dos filhos. Situação que pôde ser constatada nos momentos em que os sujeitos exerciam posições que historicamente são destinadas ao outro gênero, como no caso de Margarete que, ao ocupar a posição de provedora, incorpora o atributo da autoridade, passando a ser reconhecida enquanto homem, e ainda nas situações em que os homens dessas famílias empreendiam no sentido de não se aproximarem de posições tidas como femininas e de tentarem exercer as reconhecidas como masculinas.

Essas circunstâncias os levaram ao questionamento de seus corpos e à elaboração de estratégias para continuarem dentro da matriz inteligível de gênero. $\mathrm{Ou}$ seja, a família Rodrigues nomeou Gabriel de filho e a Santos permaneceu nomeando seus integrantes segundo as posições estabelecidas anteriormente para cada um deles. Essas nomeações delimitam formas de agir no mundo, enquanto os adjetivos designados a cada nome definem o modo de ação, sendo que a ação da nomeação, bem como de seus modos de ação, produzem sujeitos e suas posições. Foucault (1999a, p. 112) define "os nomes como formas, os adjetivos como cores e o verbo (ser) como a própria tela onde elas aparecem". Assim, se Gabriel recebe o nome de filho e porta-se como tal, ele pode ser sustentado por sua companheira, e Aline, ao não receber o nome de provedora, pode ser dona de casa, e Marcos trabalhador. A força do nome decorre de sua historicidade por "funcionar em parte através de uma memória codificada ou de um trauma, uma memória que vive na linguagem e que a linguagem transmite" (Butler, 1997, p. 65).

Nota-se, portanto, que por mais que haja subversões às normas a partir do exercício de atributos ininteligíveis de gênero, numa lógica que poderia ser considerada mais igualitária, os sujeitos acabam por reiterá-las por meio de procedimentos que visam a viabilizar suas existências, permanecendo as iniquidades. 
Essas empreitadas alicerçam a percepção de que os gêneros masculinos e femininos não sejam "naturais", justamente por haver a necessidade de sua negociação e reivindicação a cada "ato de fala" (Butler, 2003).

A repetição da norma acaba por demonstrar a sua volatilidade, bem como a posição de vulnerabilidade em que os sujeitos se encontram, o que os impele a todo o momento a atuarem performaticamente. Contudo, pôdese perceber a existência de uma cobrança da família, que é a representante do Estado, e do social maior para com os homens, afinal suas companheiras sempre puderam trabalhar, contanto que eles também o fizessem, além de terem de, ao menos, colaborar com as despesas do lar. Ao se verem impossibilitados de cumprirem com suas obrigações de "homens", sentem-se envergonhados e desonrados por terem fracassado e ainda terem que depender de suas esposas, como se não fossem "homens de verdade". O que permite inferir que existem possibilidades das mulheres exercerem posições masculinas, desde que não se abstenham do exercício das femininas, e que os homens devem exercer primordialmente as masculinas, por mais que, como no caso de Gabriel, que se tornou "dono de casa", exerçam as femininas. É importante lembrar que o fato de ele ter adentrado em uma posição feminina foi viável justamente pela nomeação que recebeu de filho, pois se for considerada somente a impossibilidade das famílias em terem uma empregada doméstica, o mesmo ocorreria com Marcos.

O sofrimento vivenciado pelas organizações familiares nessa situação pôde ser percebido também no silêncio proferido por essas, e, principalmente, pelos homens, ao reagirem com esquiva diante da possibilidade de serem sujeitos desta pesquisa. Silenciar-se, para esses homens, pode ser uma maneira de não entrar em contato com a dor, ou ainda, não expô-la a uma estranha, no caso a pesquisadora. A exposição dessa dor, segundo os participantes deste estudo, causa vergonha, vergonha por sentirem dor, mostrarem sua fragilidade, por falharem, fracassarem no cumprimento do almejado ideal masculino. Pode-se supor, então, que o silêncio também produz subjetividades, na medida em que preserva a condição de um homem, pai trabalhador. Ao se calar, o sujeito reafirma a sua identificação enquanto trabalhador, não possibilitando outras.

Diante dessas circunstâncias, percebe-se que, por mais que haja deslizamentos dos sujeitos entre as posições de gênero masculinas e femininas, eles almejam retornar e fixar-se em uma dessas, desejam ser submetidos à submissão às normas, para que, assim, possam ser reconhecidos por outros como homens e mulheres, por mais que, às vezes, as questionassem e tentassem não reiterá-las. Há, portanto, uma flexibilidade ilusória nesses processos de assujeitamento, justamente pela exigência de conformidade com a norma.
As práticas discursivas dessas famílias são atravessadas pelo enunciado trabalho, o qual propicia a produção de práticas cotidianas e masculinidades nessas famílias calcadas nas normas de gênero, que determinam que o homem, para ser considerado "homem", deva trabalhar e sustentar a família. Sendo que, a partir do momento em que as mulheres exercem tais mandatos, passam a ser consideradas "homens", e os homens sentem-se desonrados por não os realizarem, como se fossem destituídos de suas posições de "homens da casa", já que essas são exercidas por suas companheiras.

No entanto, a própria repetição e reiteração da norma abre espaços para a resistência, para novos modos de vida, uma vez que o que importa não é a repetição em si, mas a forma como é repetida. Então, mediante esse cenário, pode-se afirmar que a possibilidade performática discursiva da repetição abriu espaços para ressignificações, abriu espaços para resistências, para subversões à norma. Ou seja, nessas famílias, em que o prover e o trabalho não estavam mais afeitos exclusivamente ao homem, a repetição de tal enunciado produziu novas formas de sujeição, de sentir, de modelos para pensar e amar. Novas possibilidades de masculinidades foram experenciadas. Quem sabe por se lançar mão do próprio mecanismo de normalização, ou seja, de se repetir e reiterar essas novas possibilidades, os vínculos entre os sujeitos sejam permeados pelo exercício de posições mais equânimes, assim como ocorre nas relações de amizade.

\section{Notas}

1 Agonismo é entendido como um estado de luta e incitação recíproca. "Trata-se, portanto, menos de uma oposição de termos que se bloqueiam mutuamente do que de uma provocação permanente" (Foucault, 1995, p. 245), incitando os sujeitos à crítica e à criação.

2 Constituída por Marcos (pai), Aline (mãe) e Marta (filha), e residente na cidade de Florianópolis (SC). Os nomes atribuídos a eles são fictícios.

3 As expressões destacadas em itálico no corpo do texto referem-se às falas dos sujeitos pertencentes à organização familiar.

4 Butler (2003) enfatiza que o gênero implica os significados culturais que são, sobretudo, performativos. Ou seja, o gênero não expressa uma "essência interior" de quem somos, e sim o que é produzido por um ritualizado jogo de práticas que consequentemente produzem o efeito de uma "essência interior". O gênero é vivido, portanto, como uma interpretação, um jogo de interpretações do corpo, que é, por fim, uma mutável e histórica instituição social.

5 O conceito de autoritário é trazido pela família como uma maneira de nomear quem detém o poder de decisão nesta organização familiar.

6 Constituída por Gabriel (pai), Margarete (mãe) e Roberta (filha), e residente na cidade de Jundiaí (SP). Os nomes atribuídos a eles são fictícios. 
7 Segundo Foucault (2001), o Panóptico pode ser aplicável a muitos domínios diferentes, não se restringindo somente à prisão. O Panóptico configura-se como um princípio geral de construção, um dispositivo polivalente de vigilância, uma máquina óptica universal das concentrações humanas. Uma vez que "é polivalente em todas as suas aplicações: serve para emendar os prisioneiros, mas também para cuidar dos doentes, instruir os escolares, guardar os loucos, fiscalizar os operários, fazer trabalhar os mendigos e ociosos" (Foucault, 2001, p. 170).

\section{Referências}

Butler, J. (1997). Lenguaje, poder e identidad. Madrid: Sintesis.

Butler, J. (1998). Fundamentos contingentes: o feminismo e a questão do pós-modernismo. Cadernos Pagu, 11, 11-42.

Butler, J. (2003). Problemas de gênero: feminismo e subversão da identidade. Rio de Janeiro: Civilização Brasileira.

Foucault, M. (1995). O sujeito e o poder. In P. Rabinow \& H. Dreyfus (Orgs.). Foucault, uma trajetória filosófica: para além do estruturalismo e da hermenêutica (pp. 229-249). Rio de Janeiro: Forense Universitária.

Foucault, M. (1999a). As palavras e as coisas: uma arqueologia das ciências humanas. São Paulo: Fontes.

Foucault, M. (1999b). Em defesa da sociedade. São Paulo: Editora Martins Fontes.

Foucault, M. (2001). Vigiar e punir. Petrópolis, RJ: Editora Vozes.

Foucault, M. (2004). A ordem do discurso. São Paulo: Loyola.

Foucault, M. (2005). História da sexualidade I: a vontade de saber. Rio de Janeiro: Edições Graal.
Hardt, M., \& Negri, A. (2001). Império. Rio de Janeiro: Record.

Vercellone, C. (2003). Sommes-nous sortis du capitalisme industriel? Paris: La Dispute.

Recebido em: 21/11/2008

Revisão em: 12 -07- 2009

Aceite final em: 07-08-2009

Grazielle Tagliamento é Psicóloga, doutoranda do programa de Pós-Graduação em Psicologia Social da USP e pesquisadora do Núcleo de Estudos para a Prevenção da AIDS (NEPAIDS) da USP. Endereço: R. Monsenhor Ivo Zanlorenzi, 3847, ap. 442. Mossunguê. Curitiba/PR, Brasil.

CEP: 81210-000.

Email: tagrazi@usp.br

Maria Juracy F. Toneli é Professora doutora do curso de Psicologia da UFSC e coordenadora do núcleo de pesquisa "Modos de vida, família e relações de gênero"

(MARGENS) da UFSC.

\section{Como citar:}

Tagliamento, G. \& Toneli, M. J. F. (2010). (Não)trabalho e masculinidades produzidas em contextos familiares de camadas médias. Psicologia \& Sociedade, 22(2), 345-354. 